\title{
Sensorial Analysis of Organic and Conventional Chicken Eggs (Gallus Gallus Domesticus)
}

\author{
Bianca SS ${ }^{*}$, Fabiola SF${ }^{2}$, Caetano B ${ }^{1}$, Marta MMC ${ }^{1}$ and Marta VBR ${ }^{1}$ \\ ${ }^{1}$ Department of Agroindustrial Technology and Rural Economy Partner (DTAiSER), \\ Brazil
}

${ }^{2}$ Federal University of Sao Carlos (UFSCar), Brazil

\section{Research Article \\ Volume 2 Issue 3}

Received Date: May 03, 2019

Published Date: May 14, 2019

DOI: $10.23880 /$ izab-16000149

*Corresponding author: Schneider S Bianca, Federal University of São Carlos (UFSCar), Center of Agrarian Sciences (CCA). Anhanguera Highway, Km 174, Caixa Postal 153, CEP 13600-970-Araras/ SP, Brazil, Email: biancasschneider@hotmail.com

\section{Abstract}

The objective of this study was to evaluate the instrumental color and sensory analysis of four brands of eggs: organic (A and B) and conventional ( $C$ and D). The analysis of skin color and yolk was performed using a Minolta ${ }^{\circledR}$ colorimeter and sensory analysis was used to rank the preference of thirty tasters. The instrumental color data were subjected to analysis of variance, and significant differences were subjected to Tukey test to detect between the means ( $\mathrm{p} \leq 0.05)$. The data were subjected to the sort Friedman test and multiple comparisons between scores. For instrumental color of the egg yolk for both luminosity and chroma sample $\mathrm{C}$ differed from the other samples. In the sensory test, significant difference appeared only for yolk color, which sample $\mathrm{C}$ appeared darker than others. For aroma and flavor, was no significant difference between samples. The differences presented by samples for instrumental color and color perceived by sensory analysis didn't affect the sensory preference and buying intentions between conventional and organic eggs studied.

Keywords: Organic Eggs; Sensory Analysis; Preference; Instrumental Color

\section{Introduction}

Based on the Statistical Data on Livestock Production generated by Brasil 2010 [1], accumulated egg production between January and September 2010 reached 1,839 billion dozens of units, representing an increase of 4.5 in relation to the previous year. Eggs are used very frequently by brazilian population, as well as presenting affordable prices, it is also part of their eating habits [2]. According to Sarcinelli, et al. [3], eggs are important protein sources, with low fat, having in their lipidic portion higher concentrations of essential fatty acids.
They exhibit various functional properties, which provide food color, viscosity, emulsification, gelling and foaming. Breeding method influences the composition of protein, fatty acids and cholesterol of the yolk. Over the past 50 years, advances in animal health, nutrition, management and genetics have resulted in a formidable and unquestionable increase in animal production and productivity. As a result of these advances, there have been significant benefits to human society as abundant and cheap food, reduced seasonality in food supply and improved product hygiene. For the animals, there were also benefits, such as protection against predators, shelter, 


\section{International Journal of Zoology and Animal Biology}

balanced nutrition and progress in disease prevention and veterinary care [4].

However, in conventional breeding process, animals were confined in smaller spaces, diet became more specialized, and there was a great consumption of fossil energy in the production process, either by the types of facilities adopted or by the energy cost of animal feed production. At the same time, the accumulation of waste has become a serious environmental problem [4].

According to Singer, et al. [5] in all developed countries people are learning to question the origin of their food and its form of production. Attitudes like this are part of a growing movement towards the ethical consumption of food. From 80's, organic movement gained size, seeking an alternative approach to agricultural production. At these farms, animals were only used to harvested plants that had been planted to fix nitrogen in the soil or to provide manure for fertilizer production, sometimes also as "live tractors" to graze or prepare the soil and also to eat unwanted insects; not being created for commercial purposes [6]. However, as shown in the following decades, animal production is an important part of an organic property, as it contributes to the balanced relationship between soil, plants and animals, nutrient recycling, fundamental in an organic system [7]. Organic animal and vegetable production grow mutually, since the food base for animal supply needs to be structured to enable the livestock sector. The market for organic products tends to expand, as it is a sector that worldwide presents in the last two decades, average growth of 20 per year [8].

Organic foods are defined as those in natura or processed foods that come from an organic system of agricultural and livestock production and industry. The production of organic food is based on techniques that do not require the use of inputs such as synthetic pesticides, chemical fertilizers, veterinary drugs, genetically modified organisms, preservatives, additives and irradiation (Food And Agriculture Organization, FAO) [9]. Based on the studies of Santos, et al. [10] it is important to note that there are few studies available in the literature on the nutritional and sensory aspects of organic foods, although several report the superiority of these foods. Based on studies analyzed by Sousa, et al. [11] concluded that although organic foods stand out because of their low toxicity, longer shelf life and higher content of some nutrients in some foods, more comparative studies should be performed to prove this superiority. In this research we analysed instrumental color and sensorial analysis of difference and preference for four egg branda, two organic (A and B) and two conventional (C and D) , and respective purchase intention.

\section{Material and Methods}

\section{Material}

Four brands of chicken eggs (Gallus gallus domesticus), two coming from organic farming system and two from conventional farming. All Farmers located in the countryside of São Paulo state.

\section{Methods}

Preparation of the samples: For each of the four egg brands, five dozen eggs were collected. The samples were sent to the laboratory, where they were baked. To perform the test, samples (half of an egg boiled in boiling water for 10 minutes) of each treatment were given for evaluation [12].

Color instrumental analysis: For the color measure of boiled eggs, we used Minolta CR-200-b colorimeter.

Sensory analysis: The project was approved by the Human Research Ethics Committee of UFSCar. Sensory analysis was performed at the UFSCar/Campus Araras Sensory Analysis Laboratory, with thirty untrained volunteer testers. The difference-ordering test was applied to the attributes of color (yolk), aroma, taste and finally ordering preference Associação Brasileira De Normas Técnicas-Abnt, 1994 [13]. Samples were coded with three letters, and served in disposable plastic dishes.

Then a dozen of each egg brand were placed in appropriate, unidentified boxes and presented to the tasters to allow them to analyze the external appearance of product. They were asked to sort samples according to purchase intention.

Questionnaire on egg consumption: The same tasters of sensory analysis were asked to complete a questionnaire about the frequency of eggs consumption: a lot (every day); moderately ( 2 to 4 times per week); occasionally (once a week); very little (less than $1 \mathrm{x}$ per week) and on the acquisition (brand, color and other factors that interfere in the choice of product). They were also questioned about the knowledge and consumption of organic eggs.

Statistical analysis: The data obtained in the color instrumental test were submitted to analysis of variance ( $F$ test), and the Tukey test was used for the comparison between averages, at 5 significance level. The ordering data of the sensorial analysis were submitted to the 


\section{International Journal of Zoology and Animal Biology}

Friedman test at 5, as suggested by Gibbons, et al. [14] among others. The test statistic $(\mathrm{H})$ is given by:

$$
\mathrm{H}=\frac{12}{\mathrm{k}(\mathrm{k}+1)} \sum_{\mathrm{j}-1}^{\mathrm{k}} \mathrm{n}_{\mathrm{j}}\left(\overline{\mathrm{r}}_{\mathrm{j}}-\overline{\mathrm{r}}\right)^{2}
$$

Where $\mathrm{k}=4$ is the number of treatments,

$\mathrm{n}_{\mathrm{j}}=30$ the number of tasters,

the average score of treatment,

$\mathrm{j}_{\mathrm{e}}=$ the average score of whole experiment.

For samples with sufficient number of observations, as in this case, $\mathrm{H}$ has a near-chi-square distribution, with $\mathrm{k}-1$ degrees of freedom. The minimum significant difference between scores (d) is given by:

$$
\mathrm{d}=\mathrm{z}_{\alpha /[\mathrm{k}(\mathrm{k}-1)]} \sqrt{\frac{1}{6} \mathrm{nk}(\mathrm{k}-1)}
$$

Where $\mathrm{z}$ is the two-tailed probability factor of the standard normal distribution for a significance $2 \alpha$ divided equally by the number of comparisons to be made. This procedure may lead, for some combinations of $\mathrm{n}$ and $\mathrm{k}$, to values slightly different from those found in the known tables, such as Newell-MacFarlane.

\section{Results and Discussion}

In the instrumental analysis of egg yolk color for both luminosity and chroma the $\mathrm{C}$ (conventional) brand was different from others. Sample C, in turn, stood out among the others, as it had a significantly higher chroma value and lower luminosity (Table 1).

Probably a differential coloring of the egg yolk is mainly due to the diet provided to laying hens. The pigmentation results from the deposition of xanthophylls (group of carotenoid pigments) in the egg yolk. The sources of carotenoid pigments may be natural, such as those of the corn and red pepper group, among others. Synthetic carotenoids, such as 10 canthaxanthin (red pigment) and ethyl ester beta apo-8-carotene (yellow pigment) may also be used [15]. Eggs with darker colored egg yolks came from laying hens treated by the conventional method.

\begin{tabular}{|c|c|c|c|c|}
\hline Brands & Luminosity (L*) & \multicolumn{2}{c|}{ Chroma (C) } \\
\hline A (organic) & $86,36 \pm 1,64$ & ab & $57,18 \pm 5,00$ & b \\
\hline B (organic) & $87,73 \pm 1,64$ & a & $55,48 \pm 5,00$ & b \\
\hline C (conventional) & $77,44 \pm 1,64$ & $\mathrm{c}$ & $72,19 \pm 5,00$ & $\mathrm{a}$ \\
\hline D (conventional) & $84,64 \pm 1,64$ & $\mathrm{~b}$ & $58,30 \pm 5,00$ & $\mathrm{~b}$ \\
\hline
\end{tabular}

Averages \pm standard deviation. Values followed by equal letters in the column do not differ significantly from each other by Tukey test at 5 significance.

Table 1: Results obtained from instrumental color analysis of cooked yolk of four egg brands Brands Luminosity (L*) Chroma (C).

Table 2 shows the sum of the scores assigned to the eggs by the 30 testers in the sorting test. For gem color, it was observed that the $\mathrm{C}$ mark was significantly darker

than the others, followed by the mark D. The marks A and B did not show differences between them.

\begin{tabular}{|c|c|c|c|c|c|c|c|c|c|c|c|c|}
\hline Brands & \multicolumn{2}{|c|}{ Purchase Intention } & \multicolumn{2}{|c|}{ Yolk Color } & \multicolumn{2}{|c|}{ Aroma } & Taste & \multicolumn{2}{|c|}{ Texture } & \multicolumn{3}{c|}{ Overall Preference } \\
\hline A (organic) & 73 & $\mathrm{a}$ & 49 & $\mathrm{c}$ & 74 & $\mathrm{a}$ & 74 & $\mathrm{a}$ & 68 & $\mathrm{ab}$ & 69 & $\mathrm{a}$ \\
\hline B (organic) & 88 & $\mathrm{a}$ & 49 & $\mathrm{c}$ & 67 & $\mathrm{a}$ & 71 & $\mathrm{a}$ & 80 & $\mathrm{ab}$ & 68 & $\mathrm{a}$ \\
\hline C (conventional) & 67 & $\mathrm{a}$ & 118 & $\mathrm{a}$ & 76 & $\mathrm{a}$ & 73 & $\mathrm{a}$ & 92 & $\mathrm{a}$ & 80 & $\mathrm{a}$ \\
\hline D (conventional) & 72 & $\mathrm{a}$ & 84 & $\mathrm{~b}$ & 83 & $\mathrm{a}$ & 82 & $\mathrm{a}$ & 60 & $\mathrm{~b}$ & 83 & $\mathrm{a}$ \\
\hline
\end{tabular}

Values followed by equal letters in the column do not differ statistically from one another by the Friedman test at 5 significance.

Table 2: Multiple comparison between sums of notes given for four egg brands Brands.

For texture, the $\mathrm{C}$ mark was highlighted as being harder than D, but they did not show any significant difference in comparison with samples A and B (conventional). According to Alleoni, et al. [16] the internal quality of the egg changes immediately after laying, due to factors such as water loss (and consequent weight loss) and $\mathrm{CO} 2$ through the bark, albume liquefaction, fluid movement between compartments, 
distention and flaccidity of the yolk membrane of the yolk, which may break. These changes alter some functional properties, such as gelatinization, which is linked to the texture and chewiness of cooked whites. Since the overall preference was not different for any sample, it can be said that the yolk color did not interfere with the consumer's choice.

The values obtained showed that there was no significant difference for the aroma, taste and overall preference and purchase intention attributes.

In a study with the traditional, semi-organic and organic forms cited by Mizumoto, et al. [12] found that management did not alter vitamin A levels and sensory characteristics. On the other hand, Quitral, et al. [17] reported in a study that organic egg samples presented better quality, as much as appearance, color and aroma, than the conventional eggs that presented better flavor.

For the results obtained in the questionnaire on family structure, it was verified that on average the families are constituted by 4 members, being their great part in the age group of 16 to 45 years. When questioned about the frequency of egg consumption, majority (60) responded that they consume moderately, that is, 2 to 4 times a week.

Table 3 shows results on preferences and acquisition habits. Most (70) buy red eggs and have no brand preferred. (76,7).

\begin{tabular}{|c|c|c|c|c|c|}
\hline \multicolumn{2}{|c|}{ Preference for some brand? } & \multicolumn{2}{|c|}{ Preferred color 0 } & \multicolumn{2}{c|}{ Reads package information? 0 } \\
\hline Yes & 23,3 & Indifferent & 10 & Yes & 40 \\
\hline & & White & 20 & & \\
\cline { 2 - 5 } & & Red & 70 & & \\
\hline
\end{tabular}

Table 3: Preferences and habits in egg acquisition.

Table 4 shows the results regarding knowledge and consumption of organic eggs. 50 of people interviewed reported knowing organic eggs, and 20 stated that they have the habit of consuming them. They describe that they consume organic eggs because consider it healthier than conventional eggs. However, 80 of respondents stated not easily find organic eggs to buy.
In fact, in the segment of organic perishable foods, commercial relations between suppliers and retail networks are complex, considering the additional supply difficulties, specific to the initial stage of development of organic farming, such as volume of production, variety of products, seasonality of production, supply discontinuity, certification requirement, among others [18].

\begin{tabular}{|c|c|c|c|c|c|}
\hline \multicolumn{2}{|c|}{ Knows organic eggs () } & \multicolumn{2}{c|}{ Consume organic eggs 0 } & \multicolumn{2}{c|}{ Finds organic eggs easily 0 } \\
\hline Yes & 50 & Yes & 20 & Yes & 6,7 \\
\hline & & & No & 80,0 \\
\cline { 4 - 5 } & & & & No response & 13,3 \\
\hline
\end{tabular}

Table 4: Responses about organic eggs consumption.

\section{Conclusion}

The differences that samples presented for instrumental color and perceptive color and sensorial texture did not interfere in the preference and intention to buy conventional and organic studied eggs.

\section{References}

1. (2010) Ministry of Planning, Budget and Management. Brazilian Institute of Geography and Statistics-IBGE. Municipal livestock production, Rio de Janeiro 38: 1-65.

2. Rodrigues KRM, Salay E (2001) Attitudes of farmers, wholesalers, retailers and consumers regarding the sanitary quality of chicken eggs in natura. Journal of Nutrition 14(3): 185-193.

3. Sarcinelli MF, Venturine KS, Silva LC (2007) Characteristics of eggs. Federal University of Espírito Santo-UFES. Technical Bulletin-PIE-UFES: 00707, Brasil.

4. Eeuu Machado Filho LCP, Bridi AM, Hötzel MJ (2007) Ethics in Animal Production. In: Pinheiro JW, et al. (Eds.), Zootechnics in the face of new challenges 1: 316.

5. Singer P, Mason JA (2007) Food Ethics: How our eating habits influence the environment and our wellbeing. Elsevier Ed. Rio de Janeiro, Brazil. 


\section{International Journal of Zoology and Animal Biology}

6. Escosteguy A (2009) Ecological breeding of animalsPart 1: Alternatives to confinement.

7. Monzote FF (2007) From livestock specialization to agroecological livestock: Cuban experiences in research and production. Brazilian Journal of Agroecology 2(2): 1761-1764.

8. Sorensen JT, Edwards S, Noordhuizen J, Gunnarsson S (2006) Animal production systems in the industrialized world. Revue Scientifique et Technique-Office International des Epizooties 25(2): 493-503.

9. FAO Inter Departmental Working Group on Organic Agriculture. Food and Agriculture Organization.

10. Santos GC, Monteiro M (2004) Organic system of food production. Food and Nutrition 15(1): 73-86.

11. Sousa AA, Azevedo E, Lima EE, Silva APF (2012) Organic food and human health: a study of the controversies. Rev Panam Salud Publica 31(6): 513 517.

12. Mizumoto EM, Canniatti Brazaca SG, Machado FMVF (2008) Chemical and sensory evaluation of eggs obtained by different treatments. Food Science and Technology 28(1).
13. Associação Brasileira De Normas Técnicas Abnt (1994) Sorting test in sensory analysis. Rio de janeiro, Brazil.

14. Gibbons JD (1992) Nonparametric statistics: an introduction. Series: Quantitative Applications in the Social Sciences, Sage University Paper, Sage Publications, Thousand Oaks, London, New Delhi.

15. Garcia EA, Arcia EA, Mendes AA, Pizzolante CC, Gonçalves HC, et al. (2002) Effect of dietary canthaxanthin levels on performance and egg quality of commercial laying hens. Brazilian Journal of Poultry Science 4(1).

16. Alleoni ACC, Antunes AJ (2005) Texture and moisture profile squeezable from egg albumen gels coated with whey. Science Food Technology 25(1).

17. Quitral V, Donoso ML, Acevedo N (2009) Physicochemical and sensorial comparison of country, organic and commercially produced eggs. Public Health and Nutrition Magazine 10 (2).

18. (2007) Mapa Ministry of Agriculture, Livestock ond Supply-Mapa. In: Batalha MO, Buainain AM, (Eds.), Production Chain of Organic Products, Agribusiness Series 5. 